Department of Anatomy (Prof. H. FujiTA), Hiroshima University School of Medicine, Hiroshima, Japan

\title{
The Occurrence of Endocrine Cells in the Intestine of the Lancelet, Branchiostoma japonicum. An Electron Microscope Study
}

\author{
Katsuko Kataoka and Hisao Fujita
}

Received February 12, 1974

\begin{abstract}
Summary. Two types of endocrine cells (type I and II) are identified by their basally aggregated secretory granules in the posterior part of the lancelet mid-gut. They are tall columnar, and face both the gut lumen and the basal lamina. The type I cell has two kinds of granules about $150 \mathrm{~m} \mu$ and $300-400 \mathrm{~m} \mu$ in diameter respectively. The content of the small granules is released by reverse pinocytosis from the basal cytoplasm into the connective tissue. This indicates that the small granules are obviously secretory in nature. However, neither the nature of the large granules nor the relationship between the large and small granules has been clarified. The type II cell has only one kind of granule, 300$400 \mathrm{~m} \mu$ in diameter. The releasing mechanism for these granules is not demonstrated in this study.
\end{abstract}

Though secretin (BAyliss and StALRING, 1902) and gastrin (EDKINS, 1905) were discovered at the beginning of this century, and basal granulated (yellow, argentaffin, argyrophile ... etc.) cells have been known for a long time, it is only in recent years that basal granulated cells were recognized by investigators as gut hormone-secreting cells. In the mammalian gastrointestinal mucosa, the occurrence of several types of basal granulated cells and their relation to gut hormones have been studied by electron microscopic methods (CAPELla et al., 1969; Forssmann et al., 1969; VASSALlo et al., 1969, 1971; KobAy ASHI et al., 1970, 1971; SASAGAwa et al., 1970, 1973; OsAKA et al., 1971). In the gastrointestinal tract of lower vertebrates, basal granulated cells were reported in frogs (GEUZE, 1971), snakes (KовAYASHI, 1967) and birds (Toner, 1964; Penttilä, 1968; Kataoka, 1974). Kataoka, (1973) identified at least 6 types of endocrine cells in the gastrointestinal tract of the frog.

In protochordates, however, only one paper has been published by BIuw and Hulting (1971) on the possible occurrence of endocrine cells. They found fine-grained cells in the lancelet intestine by light microscopy and suggested the probable endocrine function of these cells. The present paper deals with the occurrence, types and fine structure of the endocrine cells in the lancelet mid-gut.

\section{Materials and Methods}

Some lancelets, Branchiostoma japonicum, were used for this study. After overnight fixation with $2.5 \%$ glutaraldehyde (phosphate buffer, $\mathrm{pH} 7.4$ ), tissue blocks were obtained from the posterior part of the mid-gut and they were post-fixed with $1 \%$ osmium tetroxide. They were then dehydrated through a graded series of ethanol and embedded in Epon epoxy resin. Thin sections, doubly stained with 
uranyl acetate and lead acetate, were examined in a Hitachi HU 11-D electron microscope.

\section{Observations}

A part of the lancelet mid-gut observed in this study is lined with a single layer of tall columnar cells and very few endocrine cells. The columnar cells are extremely slender and have elongated nuclei. The rough-surfaced endoplasmic reticulum is relatively poor in development. The Golgi apparatus is located in the supranuclear region. A cilium and some microvilli project from the cell apex to the gut lumen. Several granules containing flocculent material are seen at the apical part of the cell. Some lysosome like granules are seen in the cytoplasm especially near the Golgi apparatus. Many glycogen particles are scattered throughout the cytoplasm.

Endocrine cells are identified by their secretory granules which are located mainly in the basal cytoplasm (Fig. 1). The granules are also seen in the supranuclear region but they are few in the apical cytoplasm (Fig. 3). These cells, very few in number between the columnar cells, are tall and slender. Their apex reaches the intestinal lumen and their basal plasma membrane faces the basal lamina. It is not clear whether or not these endocrine cells have a cilium at the cell apex. The nucleus is elongated and the chromatin is coarser than that of the columnar cell. Elements of the rough-surfaced endoplasmic reticulum are relatively small in number and some make parallel arrays in the perinuclear region and near the Golgi apparatus where the secretory granules are formed (Fig. 4). Abundant glycogen particles are scattered throughout the cytoplasm.

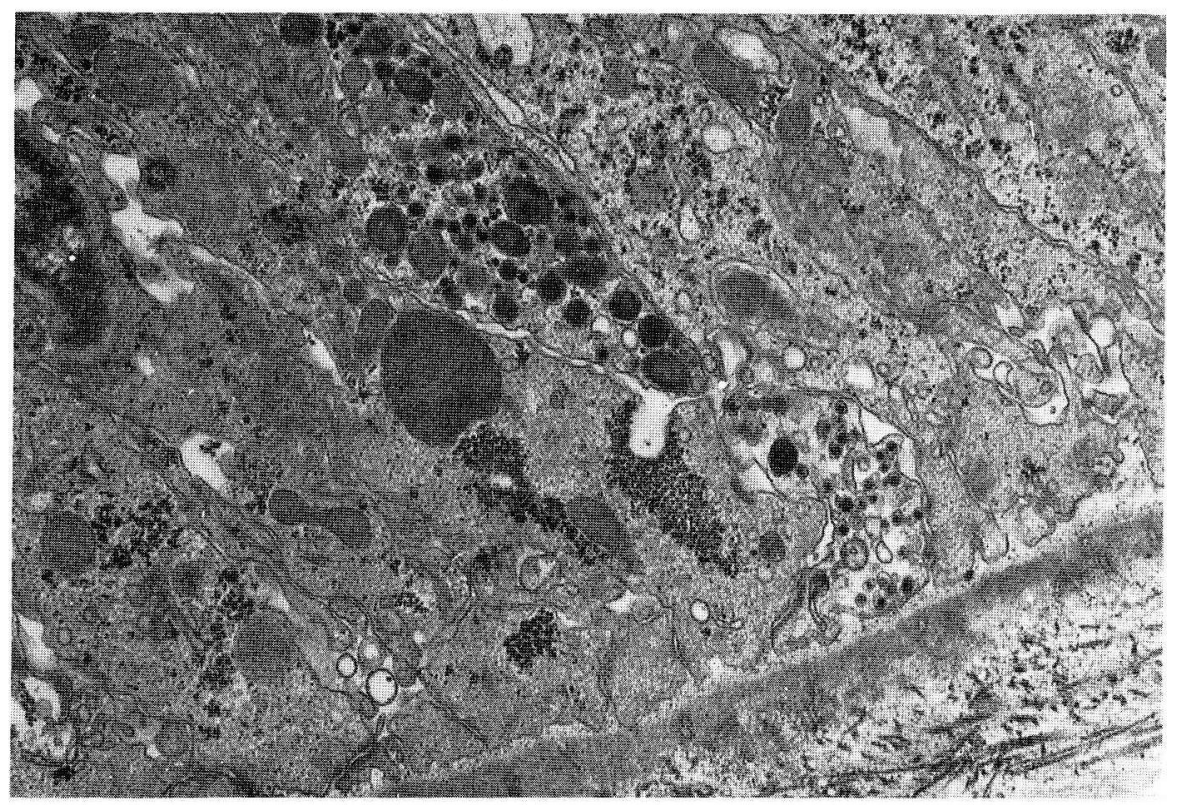

Fig. 1. The basal part of the epithelium. An endocrine cell (type I) containing numerous small and large granules is seen between columnar cells. $\times 12,000$ 
Two types of endocrine cells can be identified in the posterior part of the mid-gut by the morphological characteristics of the secretory granules (Fig. 2). The type I cell has two kinds of granules; one, about $150 \mathrm{~m} \mu$ and the other $300-400 \mathrm{~m} \mu$ in diameter. The small granules consist of a central core and a limiting membrane with a clear halo between them. The content of the small granules occasionally is recognized to be discharged by reverse pinocytosis from the lower lateral and basal parts of the cell into the intercellular space and con-

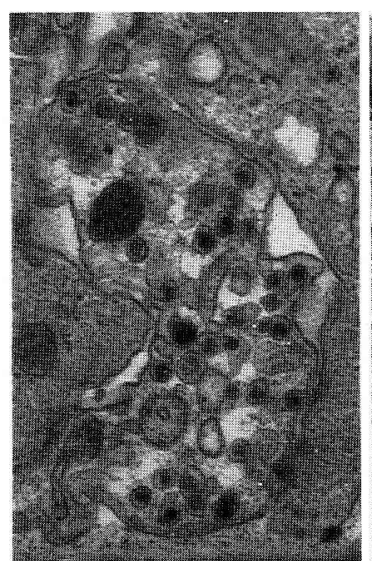

a

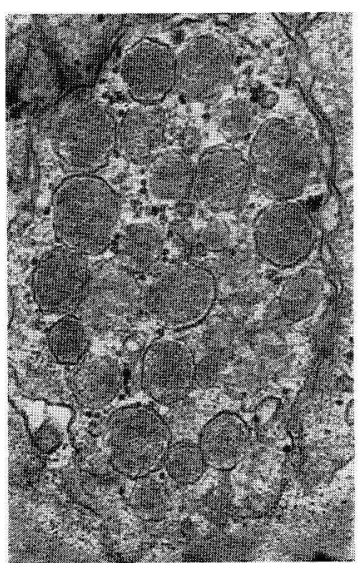

b

Fig. 2. Basal parts of type I (a) and type II (b) cells. a, b: $\times 21,000$

nective tissue. This finding indicates that the type I cell is endocrine in nature and suggests that its small granules contain a hormone. The large granule also has an electron dense granular content, clear halo and a limiting membrane. The nature of the large granules and their relationship to the small ones are obscure.

The other type of endocrine cell (type II) is less numerous than the type I cell. The type II cell has a single kind of granule $300-400 \mathrm{~m} \mu$ in diameter. Their size is about that of the large granules in the type I cell, but their contents are less electron dense. The space between the dense core and the surrounding limiting membrane is not clear. Though no evidence supporting the secretion of the granular content has been obtained in this study, the basal aggregation of the granules suggests the endocrine nature of this type cell.

\section{Discussion}

This study demonstrates the occurrence of two probable types of endocrine cells in the posterior part of the lancelet mid-gut by electron microscopy. Type I cell contains small endocrine granules and also large granules of unknown nature.

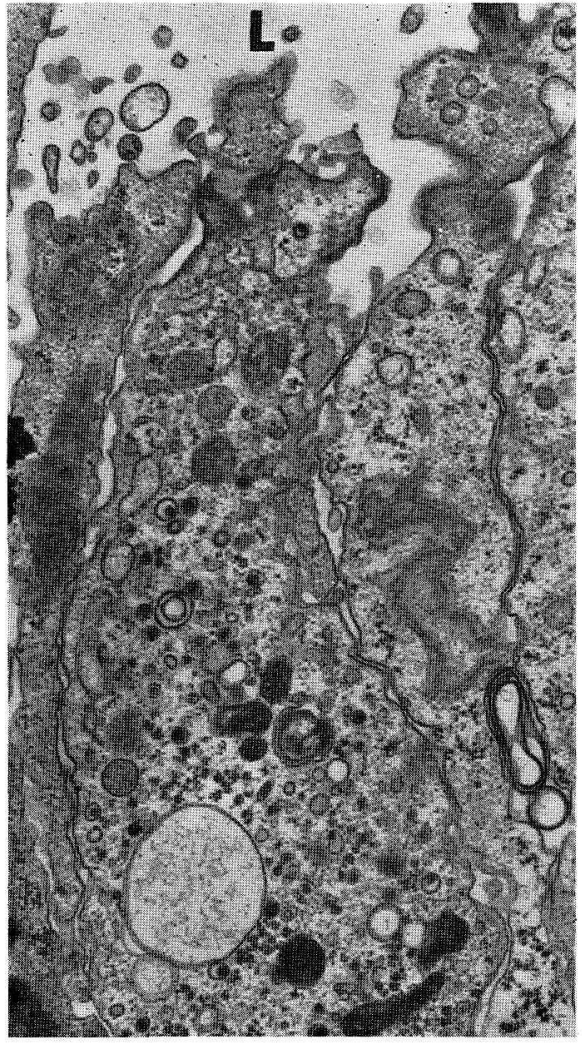

Fig. 3. Apical part of a type I cell. The number of secretory granules is very small in the apical cytoplasm. L gut lumen. $\times 14,000$ 
The content of the small granules is released by reverse pinocytosis.

The type II cell also is believed to be an endocrine cell. Though the size of their granules is similar to that of the large granules in the type I cell, the electron density of the former is markedly less than that of the latter. In the basal part of the type II cell small granules are not found whereas small granules are far more numerous than large granules in the type I cell. For these reasons the present authors believe that the type I and the type II cells are different from one another.

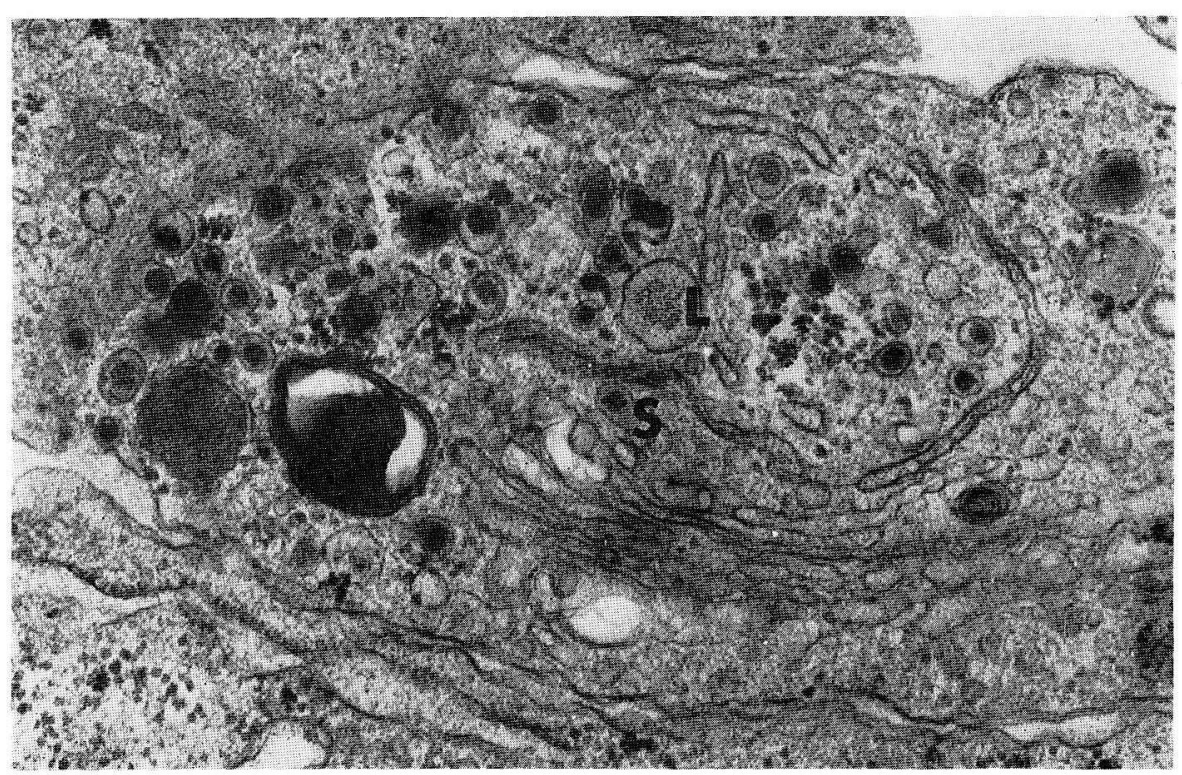

Fig. 4. Golgi area of a type I cell. The formation of small $(S)$ and large $(L)$ granules is seen. $\times 42,000$

Biuw and Hulting (1971) using the light microscope and several stainings including a toluidine blue method described fine-grained cells in the posterior part of the gut of the lancelet, Branchiostoma lanceolatum. In the Branchiostoma japonicum the present authors found similar cells also after staining with toluidine blue. Toluidine blue-stained cells are present in a very restricted area as described by Buw and Hulting (1971). It is difficult to determine whether the type I or type II cell corresponds to the fine-grained cell observed by light microscopy. Biuw and Hulting (1971) suggested exocrine as well as endocrine functions for the fine-grained cell. The present electron microscope examination reveals that endocrine granules were distributed in the supranuclear region as well as in the basal cytoplasm in contrast to the typical basal granulated cell in mammals. However, there are few granules close to the apical cell end and there are no signs suggesting an exocrine function of the cell. It is possible that the endocrine granules are stored in the supranuclear region preceding their migration to the basal cytoplasm from where they are released, and that the secretion cycle of the fine-grained cells described by Biuw and Hulting (1971) corresponds to a cycle of storage, migration and release of endocrine granules. The possibility that endocrine cells observed in this study and the fine-grained cells 
of Biuw and Hulting (1971) are independent cell types cannot be excluded, because an electron microscope study allows the examination of only a small part of the intestine and the fine-grained cells seem to occur in very restricted areas.

\section{ナメクジウオの腸に存在する内分泌細胞について．電子顕微鏡による研究}

$$
\text { 片 岡 勝子と藤田劣男 }
$$

ナメクジウオ中腸後部の上皮内に 2 種類の内分泌細胞（I 型，II 型）が同定された. 両細胞ともに背の高い円柱状で，細胞の先端は腸の内腔に，基底部は基底膜に面してい る. 細胞の基底部と核上部には多数の分泌顆粒が含まれる.

I 型内分泌細胞は直径約 $150 \mathrm{~m} \mu$ および $300 \sim 400 \mathrm{~m} \mu$ の 2 種の顆粒をもっている. 小型 の顆粒は分泌顆粒で，その内容は開口方式によって細胞基底部から上皮下の結合組織に 放出される. 大型の顆粒の性質や，それと小型の顆粒との関係は明らかにできなかった。 II 型細胞は直径 300 400 m $\mu$ の分泌顆粒をもっているが，その分泌形式については証 明できなかった。

\section{References}

Bayliss, W. M. and E. H. Starling: The mechanism of pancreatic secretion. J. Physiol. (Lond.) 28: 325-353 (1902).

Biuw, L. W. and G. Hulting: Fine-grained secretory cells in the intestine of the lancelet, Branchiostoma (Amphioxus) lanceolatum, studied by light microscopy. Z. Zellforsch. 120: 546-554 (1971).

Capella, C., E. Solcia and G. Vassallo: Identification of six types of endocrine cells in the gastrointestinal mucosa of the rabbit. Arch. histol. jap. 30: 479-495 (1969).

Edkins, J. S.: On the chemical mechanism of gastric secretion. Proc. Roy. Soc. London B 76: 376 (1905).

Forssmann, W. G., L. Orci, R. Pictet, A. E. Renold and C. Rouiller: The endocrine cells in the epithelium of the gastrointestinal mucosa of the rat. An electron microscope study. J. Cell Biol. 40: 692-715 (1969).

Geuze, J. J.: Light and electron microscope observations on the gastric mucosa of the frog (Rana esculenta). I. Normal structure. Z. Zellfrosch. 117: 87-102 (1971).

Kataoka, K.: An electron microscope study of the gastro-enteric endocrine cells of the frog, Rana nigromaculata nigromaculata. In: (ed. by) T. Fujita: Gastro-entero-pancreatic endocrine system. A cell-biological approach. Tokyo, Igaku Shoin Ltd., 1973. (p. 39-48).

-: An electron microscope study on a neuro-endocrine complex in the proventricular mucosa of the finch, Uroloncha striata var. domestica. Arch. histol. jap. 36: 391-400 (1974).

Kobayashi, S.: An electron microscope study of the intestinal mucosa of the snake, Elephe quadrivirgata (Boie). Arch. histol. jap. 28: 525-536 (1967).

Kobayashi, S., T. Fujita and T. Sasagawa: The endocrine cells of human duodenal mucosa. An electron microscope study. Arch. histol. jap. 31: 477-494 (1970).

gastric fundus. Arch. histol. jap. 32: 429-444 (1971).

Osaka, M., T. Sasagawa, S. Kobayashi and T. Fujita: The endocrine cells in the human colon and rectum. An electron microscope study of biopsy materials. Arch. histol. jap. 33: 247-260 (1971). 
Pearse, A. G. E., I. Coulling, B. Weavers and S. Friesen: The endocrine polypeptide cells of the human stomach, duodenum and jejunum. Gut 11: 649-658 (1970).

Penttilä, A.: Enterochromaffin cells in the chicken duodenum during prenatal development. $Z$. Zellforsch. 91: 380-390 (1968).

Sasagawa, T., S. Kobayashi and T. Fujita: The endocrine cells in the human pyloric antrum. An electron microscope study of biopsy materials. Arch. histol. jap. 32: 275-288 (1970).

gut and microscope studies on the endocrine cells of the human gut and pancreas. In: (ed. by) T. Fujita: Gastro-entero-pancreatic endocrine system. A cellbiological approach. Tokyo, Igaku Shoin Ltd., 1973. (p. 17-38).

Toner, P. G.: Fine structure of argyrophil and argentaffin cells in the gastro-intestinal tract of the fowl. Z. Zellforsch. 63: 830-839 (1964).

Vassallo, G., C. Capella and E. Solcia: Endocrine cells of the human gastric mucosa. Z. Zellforsch. 118: 49-67 (1971).

Vassallo, G., E. Solcia and C. Capella: Light and electron microscopic identification of several types of endocrine cells in the gastro-intestinal mucosa of the cat. Z. Zellforsch. 98: 333-356 (1969).

片岡勝子

T734 広島市霞 1 丁目 $2-3$

広島大学医学部

第二解剖学教室
Dr. Katsuko KataоKA

Department of Anatomy

Hiroshima University School of Medicine

Kasumi 1-2-3, Hiroshima, 734 Japan 